\title{
Protein and Amino Acid Solubilization using Bacillus cereus, Bacillus velesensis, and Chryseobacterium sp. from Chemical Extraction Protein Residue
}

\author{
Vilásia Guimarães Martins • \\ Jorge Alberto Vieira Costa • Silvana Terra Silveira • \\ Adriano Brandelli • Carlos Prentice
}

Received: 17 June 2008 / Accepted: 28 November 2008 /Published online: 23 December 2008

(C) Springer Science + Business Media, LLC 2008

\begin{abstract}
The exploitation of natural resources and increased environmental pollution have stressed the need for more valued use of residues generated by the fish processing plants, and species with low commercial value. Protein hydrolysis processes - whether chemical or enzymaticgenerate insoluble proteins from bones, scales, and skin, which are not recovered and are often used as animal feed or disposed off into the environment. As an alternative, insoluble proteins could be converted in useful biomass protein concentrates or amino acids, by using microbial proteases. This work examines the solubilization of insoluble proteins discarded in the process of $\mathrm{pH}$ change in fish residues from Whitemouth croaker (Micropogonias furnieri), through the use of bacterial proteases. Temperature and $\mathrm{pH}$ conditions
\end{abstract}

V. G. Martins $\cdot$ C. Prentice $(\triangle)$

Laboratório de Tecnologia de Alimentos, Escola de Química e

Alimentos, Universidade Federal do Rio Grande,

Rua Alfredo Huch, 475,

96201-900 Rio Grande, RS, Brazil

e-mail: dqmprent@furg.br

J. A. Vieira Costa

Laboratório de Engenharia Bioquímica, Escola de Química e

Alimentos, Universidade Federal do Rio Grande,

Rua Alfredo Huch, 475,

96201-900 Rio Grande, RS, Brazil

\section{S. T. Silveira $\cdot$ A. Brandelli}

Laboratório de Bioquímica e Microbiologia Aplicada,

Departamento de Ciências dos Alimentos,

Instituto de Ciência e Tecnologia de Alimentos,

Universidade Federal do Rio Grande do Sul,

Av. Bento Gonçalves, 9500,

91501-970 Porto Alegre, Brazil in the fermentations were adjusted for each microorganism and time was set at $96 \mathrm{~h}$. Two substrates (acid and alkaline), three microorganism strains, and the substrate concentration used were examined. Among the three strains, Bacillus velesensis reached the higher proteolytic activity (47.56 $\mathrm{U} \mathrm{mL}^{-1}$ ), followed by Chryseobacterium sp. with $23.46 \mathrm{U} \mathrm{mL}^{-1}$. Bacillus cereus $\left(3.13 \mathrm{U} \mathrm{mL}^{-1}\right.$ ) showed low proteolytic activity. B. velesensis was the bacterium that presented better results with the analyzed substrates, achieving larger amount of soluble protein and free amino acids. The findings showed that these bacteria could be used to solubilize proteins from fish byproducts, which may be particularly useful to increase the yield of hydrolysis process or food formulations.

Keywords Bacterial proteases · Fish · Insoluble proteins . Solubilization

\section{Introduction}

The use of a pH-change process to obtain fish muscle proteins may result in improved yields and increased added value to sea-based products (Gildberg et al. 2002; PerezMateos et al. 2004; Costa et al. 2005; Kristinsson and Liang 2006). During this process, the production of highly functional and stable protein out of byproducts from fish industrialization has received special attention. However, a considerable amount of insoluble proteins from bones, skin, connective tissue, cell membranes, and scales is generated. These insoluble materials could be hydrolyzed by specific proteases, resulting in peptides and amino acids that can be used for several purposes (Kristinsson and Liang 2006; Lempek et al. 2007). The use of protein isolates could be 
increased with an assessment of all fractions after the solubilization of muscle proteins by finding new uses for the insoluble fraction (Kristinsson and Ingadottir 2006). Few studies were conducted on the evaluation of the insoluble portion. The process might have its value significantly enhanced if it is continued (Slizyte et al. 2005).

Fibrous proteins are abundantly available as byproducts of agroindustrial processing. Horns, hooves, feathers, nails, scales, thorns, and hair may be converted in useful biomass, such as protein and amino acid concentrates, through the use of microbial enzymes (Anwar and Saleemuddin 1998; Aurrekoetxea and Perera 2001; Hulse 2004). However, the current processes to obtain feather meal are expensive and also destroy certain amino acids, yielding a product with poor digestibility and variable nutrient quality (Wang and Parsons 1997). Indeed, it is recognized that digestive enzymes, such as trypsin and pepsin, digest feather protein poorly. The rupture of insoluble macromolecules, such as collagen, elastin, and keratin, depends on the microbial secretion of extracellular enzymes that have activity on the compact surface of those molecules (Aspmo et al. 2005; Riffel et al. 2007; Brandelli 2008).

Keratin is a structural protein found in feathers, scales, wool, and hair, which is abundantly distributed in nature. It is resistant to the degradation by common proteases, such as trypsin, pepsin, and papain (Papadopoulos et al. 1986; Shih 1993). This property is mainly associated to the molecular composition and conformation of the amino acids found in keratin, which are tightly packed in the $\alpha$-helix or $\beta$-sheet into a supercoiled polypeptidic chain, because of the high degree of cross-linking by disulfide bonds, hydrogen bonding and hydrophobic interactions, keratin is insoluble and shows high mechanical stability and resistance to proteolysis (Parry and North 1998). However, keratin will not be present in nature, since it may be degraded by microorganisms (Onifade et al. 1998; Gupta and Ramnani 2006).

The hydrolysis of insoluble proteins is known among Bacillus spp. Many strains of Bacillus licheniformis and Bacillus subtilis are described as keratinolytic and/or collagenolytic (Lin et al. 1999; Suh and Lee 2001). Other species, like Bacillus pumilus and Bacillus cereus also produce keratinases (Kim et al. 2001; Werlang and Brandelli 2005). Chryseobacterium strains have been isolated from several ecosystems, such as water, soil, fish, marine environments, and clinical samples. Many strains of Chryseobacterium show high proteolytic activity (Jooste and Britz 1986; Yamaguchi and Yokoe 2000).

Collagen is the main organic constituent in bones. It is the major component of the extracellular matrix, a biomaterial that provides structural integrity for multicellular animals, through the formation of a supporting structure for their cells or organs. The molecular structure of collagen is recognized by its typical amino acid composition (Miller and Parker 1984; Luiten et al. 2003). The polypeptidic chains are composed of numerous, repeated tripeptide units of the Gly-Pro-X type, where X is often proline, modified after the translation to hydroxyproline (Vieille and Zeikus 2001; Watanabe 2004).

Considering the biotechnological potential of those microorganisms, the present work has the aim of evaluating the potential of B. cereus, B. velesensis, and Chryseobacterium sp. to hydrolyze insoluble proteins, byproducts from the production of Whitemouth croaker (Micropogonias furnieri) protein isolates.

\section{Material and Methods}

\section{Raw Material}

A fish specie was used, the Whitemouth croaker $(M$. furnieri), obtained at fish processing companies from the city of Rio Grande, in the state of Rio Grande do Sul. The fish was transported in ice-filled containers to the Food Technology Laboratory at Federal University of Rio Grande, where processing took place. Then, the fish was immediately washed with chlorinated water, beheaded, eviscerated, and filleted. The waste, such as visceras, bones, scales, skin, and head, were placed in plastic containers and stored frozen at $-18^{\circ} \mathrm{C}$, pending use.

\section{Insoluble Fish Substrate}

Two kinds of insoluble residues were used as substrate, both resulting from the production of isolated fish protein through $\mathrm{pH}$ change. First, two processes of chemical solubilization (acid and alkaline) were conducted to obtain the protein isolate from wastes of fish. Samples were homogenized with distilled water (proportion 5:1, watersubstrate). The reaction was conducted in a closed reactor, under stirring and controlled temperature. The alkalinizing agent was $1 \mathrm{~mol} \mathrm{l}^{-1} \mathrm{NaOH}$ and the acidifying agent was $1 \mathrm{~mol}^{-1} \mathrm{HCl}$. Acid solubilization was performed under pH 2.5 for $20 \mathrm{~min}$ at $30^{\circ} \mathrm{C}$ and alkaline solubilization was carried out at $\mathrm{pH} 12$ for $20 \mathrm{~min}$ at $20^{\circ} \mathrm{C}$ (Santos 2006). After solubilization, the substrate was centrifuged at $9,000 \times g$ for $15 \mathrm{~min}$. During centrifugation, the samples were separated in three phases. The upper phase (neutral lipids) was discarded, the middle phase (soluble proteins) was subjected to isoeletric protein precipitation, and the bottom phase (insoluble proteins) was reserved for further processing. The insoluble proteins were dehydrated in a tray-dryer for $13 \mathrm{~h}$ at $50{ }^{\circ} \mathrm{C}$. After that, it was ground in a knife-mill, in order to standardize the particle size as $1 \mathrm{~mm}$, and then it is used in the fermentation. 
Microorganisms

Bacterial strains designated as Chryseobacterium sp. strain kr6 (Riffel et al. 2003) and B. cereus strain kr16 (Werlang and Brandelli 2005) were isolated from feather waste and B. velesensis strain P11 (Giongo et al. 2007) was isolated from aquatic environment of the Brazilian Amazon basin (Manaus, Brazil). These microorganisms were chosen by their known keratinolytic activity that were tested before in feathers keratin. The bacteria were maintained at $4{ }^{\circ} \mathrm{C}$ in feather meal agar plates (Sangali and Brandelli 2000).

Fermentative Process

The strains were cultivated in a mineral salt medium $(0.5 \mathrm{~g}$ $\left.\mathrm{L}^{-1} \mathrm{NaCl}, 0.4 \mathrm{~g} \mathrm{~L}^{-1} \mathrm{KH}_{2} \mathrm{PO}_{4}, 0.015 \mathrm{~g} \mathrm{~L}^{-1} \mathrm{CaCl}_{2} 2 \mathrm{H}_{2} \mathrm{O}\right)$, containing different concentrations of acid and alkaline substrate, according to the experimental design (see below). The process was carried out under aseptic conditions in $250 \mathrm{~mL}$ erlenmeyer flasks containing $100 \mathrm{~mL}$ of autoclaved medium and initial $\mathrm{pH}$ adjusted to 8.0 for $\mathrm{kr} 6$ and 7.0 for kr16 and P11. Subsequently, $1 \mathrm{~mL}$ of the starter culture was aseptically transferred to $100 \mathrm{~mL}$ of medium, which supply $10^{6}$ ufc $\mathrm{mL}^{-1}$. The flasks were incubated at $30{ }^{\circ} \mathrm{C}(\mathrm{kr} 6)$ and $37{ }^{\circ} \mathrm{C}(\mathrm{kr} 16$ and P11) in an orbital shaker at $150 \mathrm{rpm}$ for $96 \mathrm{~h}$.

\section{Cellular Concentration}

The cellular concentration was monitored by measuring the colony forming units (cfu) $\mathrm{mL}^{-1}$, as described elsewhere (Sangali and Brandelli 2000). The bacterial suspension was diluted to $10^{-5}$ in phosphate-buffered saline, $100 \mu \mathrm{L}$ of sample in $900 \mu \mathrm{L}$ of $\mathrm{NaCl} 0.85 \%$. The samples were then homogenized and loaded $(20 \mu \mathrm{l})$ in triplicate onto nutrient tryptic soy agar plates, which were incubated for $48 \mathrm{~h}$ at $37^{\circ} \mathrm{C}$.

\section{Enzyme Activity}

Enzyme activity was measured as described elsewhere (Thys et al. 2004), using azocasein as substrate. The enzyme solution $(120 \mu \mathrm{L})$ was added to $480 \mu \mathrm{L}$ of azocasein solution $\left(10 \mathrm{mg} \mathrm{mL}^{-1}\right)$ in reaction $25 \mathrm{mmol} \mathrm{L}^{-1}$ tris $\mathrm{HCl}$ buffer $\mathrm{pH}$ 8. The mixture was incubated at $45^{\circ} \mathrm{C}$ for $40 \mathrm{~min}$ and the reaction was stopped by adding $600 \mu \mathrm{L}$ of $10 \%(w / v)$ trichloroacetic acid and leaving the preparation on $10^{\circ} \mathrm{C}$ for $10 \mathrm{~min}$. The mixture was then centrifuged at $10,000 \times g$ for $5 \mathrm{~min}$ and $800 \mu \mathrm{L}$ of the supernatant was added to $200 \mu \mathrm{L}$ of $1.8 \mathrm{~mol} \mathrm{~L}{ }^{-1} \mathrm{NaOH}$. Absorbance at $420 \mathrm{~nm}$ was measured with a Hitachi U-1100 spectrophotometer (Hitachi, Tokyo, Japan). One unit of enzyme activity was defined as the amount of protein that resulted in an increase of absorbance at $420 \mathrm{~nm}$ of 0.01 , under the assay conditions used.

Free Amino Acid Concentration

The free amino acid concentration was measured as described elsewhere (Moore 1968). Samples $(100 \mu \mathrm{L})$ were added to $2 \mathrm{~mL}$ of $0.1 \mathrm{~mol} \mathrm{~L}^{-1}$ phosphate buffer $\mathrm{pH} 7.2$, then $500 \mu \mathrm{L}$ of these samples were mixed with $500 \mu \mathrm{L}$ of $50 \mathrm{mg} \mathrm{mL} \mathrm{m}^{-1}$ ninhydrin. The mixture was incubated at $100{ }^{\circ} \mathrm{C}$ for $15 \mathrm{~min}$ followed by an ice bath to reach room temperature. Then, $5 \mathrm{~mL}$ of $50 \%(v / v)$ ethanol were added to the tubes. The analysis was performed in triplicate and the absorbance at $560 \mathrm{~nm}$ was measured in a Shimadzu UV/ VIS mini-1240 spectrophotometer. A control was simultaneously prepared using distilled water $(100 \mu \mathrm{L})$ instead of the sample. The standard curve was developed with glycine.

\section{Soluble Protein}

The concentration of soluble protein was determined by the Folin phenol reagent method (Lowry et al. 1951) with bovine serum albumin as a standard protein. Briefly, $200 \mu \mathrm{L}$ of the sample were added to $2.5 \mathrm{~mL}$ of combined reagent $\left(5 \mathrm{~g} \mathrm{~L}^{-1} \mathrm{CuSO}_{4} 5 \mathrm{H}_{2} \mathrm{O}\right.$ and $10 \mathrm{~g} \mathrm{~L}^{-1} \mathrm{KNaC}_{4} \mathrm{H}_{4} \mathrm{O}_{6}$ $4 \mathrm{H}_{2} \mathrm{O}$ in $20 \mathrm{~g} \mathrm{~L}^{-1} \mathrm{NaCO}_{3}$ ) and incubated for $10 \mathrm{~min}$ at room temperature. Then, $300 \mu \mathrm{L}$ of Folin-Ciocalteau's reagent were added with dilution ratio of 1:1 (Folin-water) and incubated for additional $30 \mathrm{~min}$. The absorbance at $750 \mathrm{~nm}$ was measured in a Hitachi U-110 spectrophotometer. A control was simultaneously prepared using distilled water $(200 \mu \mathrm{L})$ instead the sample.

\section{Experimental Design}

A mixed factorial experimental design $\left(3^{2} \times 2^{1}\right)$ was applied. The variables studied were substrate type, microorganism, and substrate concentration in the cultivation medium. Table 1 shows the factors assessed and their respective variations. All analyses were conducted as triplicates and at each $24 \mathrm{~h}$ along the fermentative process. For each analysis, the time with the most expressive response was distinguished and then the statistical analysis was performed. The software used was Statistic 6.0.

\section{Results and Discussion}

The highest cell concentrations were found for Chryseobacterium $\mathrm{sp}$. in both substrates, acid $\left(4 \times 10^{9} \mathrm{cfu} \mathrm{mL}^{-1}\right)$ and alkaline $\left(3 \times 10^{9} \mathrm{cfu} \mathrm{mL}^{-1}\right)$. The acid substrate provided the highest concentrations, despite of the substrate concentration 
Table 1 Factors evaluated and respectively levels of performed experiments

\begin{tabular}{llll}
\hline Variable & -1 & Level 0 & +1 \\
\hline Substrate & Acid & Not applied & Alkaline \\
Microorganism & Chryseobacterium & $\begin{array}{c}\text { Bacillus } \\
\text { cereus }\end{array}$ & $\begin{array}{c}\text { Bacillus } \\
\text { velesensis }\end{array}$ \\
& sp. kr6 & kr16 & P11 \\
Substrate & 10 & 20 & 30 \\
$\begin{array}{l}\text { concentration } \\
\left(\mathrm{g} \mathrm{L}^{-1}\right)\end{array}$ & & & \\
\hline
\end{tabular}

used, the Chryseobacterium sp. reached the concentration $10 \mathrm{~g} \mathrm{~L}^{-1}\left(2 \times 10^{9} \mathrm{ufc} \mathrm{mL}^{-1}\right), 20 \mathrm{~g} \mathrm{~L}^{-1}\left(4 \times 10^{9} \mathrm{ufc} \mathrm{mL}^{-1}\right)$ and $30 \mathrm{~g} \mathrm{~L}^{-1}\left(2.5 \times 10^{9}\right.$ ufc $\left.\mathrm{mL}^{-1}\right)$. B. cereus reached maximum values around $1 \times 10^{8}$ ufc $\mathrm{mL}^{-1}$, after $96 \mathrm{~h}$ of cultivation, regardless of substrate concentration and substrate type. $B$. velesensis reached the best values at the concentration of substrate $20 \mathrm{~g} \mathrm{~L}^{-1}$, alkaline $\left(3.6 \times 10^{8} \mathrm{cfu} \mathrm{mL}^{-1}\right)$ and acid $\left(1.3 \times 10^{8} \mathrm{cfu} \mathrm{mL}^{-1}\right)$ substrate, in the other concentrations the maximum values were around $4 \times 10^{7} \mathrm{cfu} \mathrm{mL}^{-1}$.

Table 2 shows the description of factorial design experiments $\left(3^{2} \times 2^{1}\right)$ for soluble proteins, free amino acids, and proteolytic activity at time that they were studied.

\section{Soluble Proteins}

The soluble protein concentration was determined along the fermentation process (Fig. 1). It was verified that for the substrate resulting from alkaline hydrolysis, the highest concentration was reached at $24 \mathrm{~h}$ for most samples. For the substrate resulting from acid hydrolysis, the highest levels were observed at $48 \mathrm{~h}$. This fact shows that the microorganisms were more able to solubilize proteins in alkaline substrate. After reaching the highest level of soluble protein, a reduction in its concentration was observed for both substrates. This reduction probably was caused by enzymes released in the medium that achieve protein consumption. However, in the acid substrate, it started to increase again at $96 \mathrm{~h}$, whereas in the alkaline substrate, the amount of soluble protein tends to stabilize. These results show that probably the acid substrate still have protein insoluble, then hydrolysis keep going, and in the alkaline substrate all the protein insoluble was already hydrolyzed. The same occurred in a study with $B$. cereus cultivated at $30{ }^{\circ} \mathrm{C}$ in medium with feather meal at $\mathrm{pH}$ 7. The study showed that the production of soluble protein had an increase up to $48 \mathrm{~h}$, and then became stable. The amount of soluble protein was around $0.6 \mathrm{mg} \mathrm{mL} \mathrm{m}^{-1}$ (Kim et al. 2001). The cultivation of Chryseobacterium sp. kr6 in a medium containing chicken feathers at $\mathrm{pH} 8$ and $30{ }^{\circ} \mathrm{C}$ resulted in the highest concentration of soluble protein at $48 \mathrm{~h}\left(2.5 \mathrm{mg} \mathrm{mL}^{-1}\right)$, decreasing to $1.6 \mathrm{mg} \mathrm{mL}^{-1}$ at $192 \mathrm{~h}$ (Riffel et al. 2003).

The concentration of soluble protein was higher than the concentration of free amino acids in all fermentation steps. The bacterium P11 was the microorganism that reached the highest degree of protein solubilization, in comparison with the other two.

The factorial design analysis had three steps, using a comparison between two bacteria. Considering that the highest solubilization occurred in two distinct times, the analysis was set for 24 and $48 \mathrm{~h}$. When comparing the behavior for kr6

Table 2 Results of factorial design experiments for soluble proteins and amino acids $\left(\mathrm{mg} \mathrm{mL}^{-1}\right)$ and proteolytic activity $\left(\mathrm{U} \mathrm{mL}^{-1}\right)$

\begin{tabular}{|c|c|c|c|c|c|c|c|}
\hline Run & Substrate & Microorganism & $\begin{array}{l}\text { Substrate } \\
\text { concentration }\end{array}$ & $\begin{array}{l}\text { Soluble proteins } \\
(24 \mathrm{~h})\end{array}$ & $\begin{array}{l}\text { Soluble proteins } \\
(48 \mathrm{~h})\end{array}$ & $\begin{array}{l}\text { Amino acids } \\
(48 \mathrm{~h})\end{array}$ & $\begin{array}{l}\text { Proteolytic activity } \\
(72 \mathrm{~h})\end{array}$ \\
\hline 1 & -1 & -1 & -1 & 0.293 & 0.695 & 0.046 & 12.883 \\
\hline 2 & -1 & -1 & 0 & 0.504 & 1.123 & 0.082 & 6.383 \\
\hline 3 & -1 & -1 & +1 & 0.848 & 1.863 & 0.114 & 5.841 \\
\hline 4 & -1 & 0 & -1 & 0.204 & 0.900 & 0.047 & 1.512 \\
\hline 5 & -1 & 0 & 0 & 0.874 & 1.378 & 0.092 & 1.991 \\
\hline 6 & -1 & 0 & +1 & 1.576 & 1.851 & 0.114 & 2.416 \\
\hline 7 & -1 & +1 & -1 & 1.544 & 2.265 & 0.058 & 38.633 \\
\hline 8 & -1 & +1 & 0 & 2.361 & 3.293 & 0.104 & 35.933 \\
\hline 9 & -1 & +1 & +1 & 3.000 & 3.631 & 0.131 & 27.316 \\
\hline 10 & +1 & -1 & -1 & 0.791 & 0.900 & 0.049 & 20.433 \\
\hline 11 & +1 & -1 & 0 & 2.374 & 1.576 & 0.100 & 15.883 \\
\hline 12 & +1 & -1 & +1 & 1.665 & 2.859 & 0.122 & 18.750 \\
\hline 13 & +1 & 0 & -1 & 1.334 & 1.270 & 0.045 & 0.695 \\
\hline 14 & +1 & 0 & 0 & 1.774 & 2.565 & 0.070 & 2.229 \\
\hline 15 & +1 & 0 & +1 & 3.331 & 2.565 & 0.091 & 1.629 \\
\hline 16 & +1 & +1 & -1 & 1.065 & 0.925 & 0.048 & 1.858 \\
\hline 17 & +1 & +1 & 0 & 2.406 & 2.208 & 0.081 & 1.441 \\
\hline 18 & +1 & +1 & +1 & 3.587 & 3.338 & 0.087 & 2.066 \\
\hline
\end{tabular}




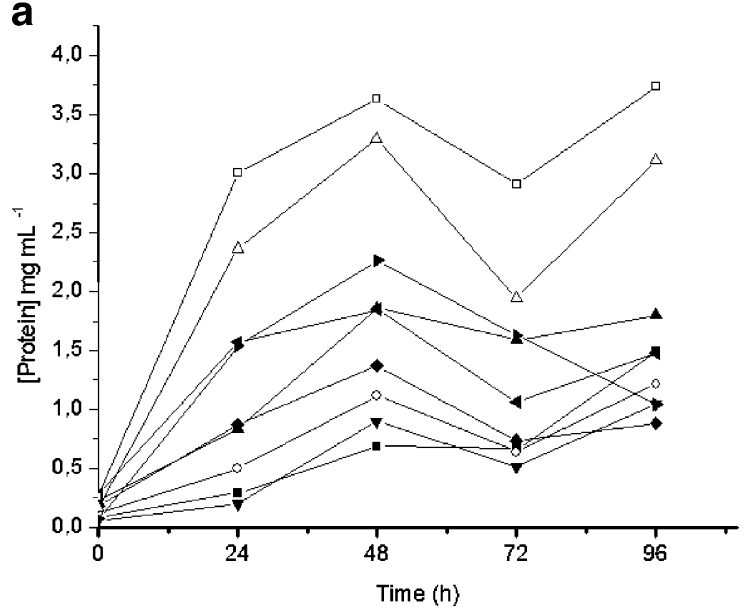

Fig. 1 Soluble protein concentration during the fermentation in both substrates a acid and $\mathbf{b}$ alkaline. Filled square $\mathrm{kr6}\left(10 \mathrm{~g} \mathrm{~L}^{-1}\right)$; unfilled circle $\mathrm{kr6}\left(20 \mathrm{~g} \mathrm{~L}^{-1}\right)$; filled triangle $\mathrm{kr6}\left(30 \mathrm{~g} \mathrm{~L}^{-1}\right)$; filled inverted

and $\mathrm{P} 11$, the significant variables $(p<0.05)$ were microorganisms and the substrate concentration used, for both time periods examined, showing the best results for P11 in the concentration of $30 \mathrm{~g} \mathrm{~L}^{-1}$. When assessing $\mathrm{kr} 6$ and $\mathrm{kr} 16$, the significant variables $(p<0.05)$ were substrate type and substrate concentration for the 48 -h period. These bacteria presented very similar values of soluble protein. When analyzing kr16 and P11, it was found that for the 24-h period all variables were significant; for the 48 -h period, only the microorganism and the substrate concentration were significant. After that analysis, it was found that the most important variables for protein solubilization were the microorganism used and the substrate concentration, showing that P11 was the strain with the best results, and the substrate concentration of $30 \mathrm{~g} \mathrm{~L}^{-1}$ was the most efficient.

Free Amino Acids

Figure 2 shows amino acid concentration along $96 \mathrm{~h}$ of fermentation for each bacterium studied. The highest concentration of free amino acids was observed with the b

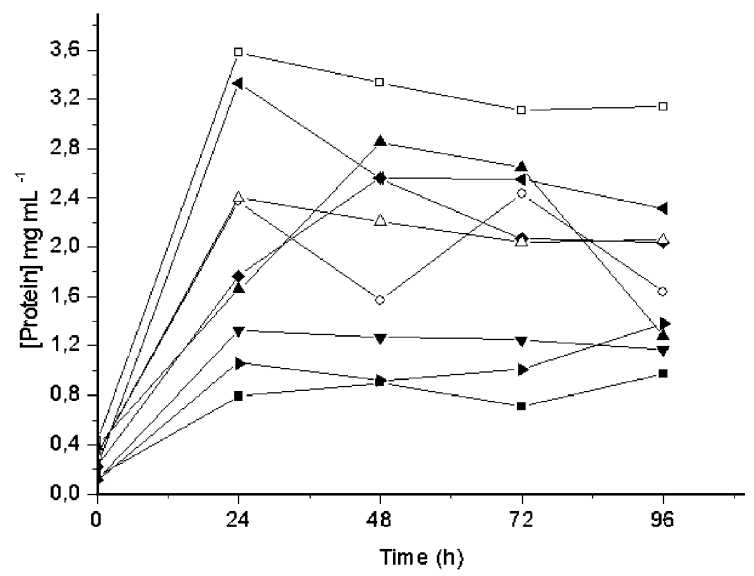

triangle $\mathrm{kr} 16\left(10 \mathrm{~g} \mathrm{~L}^{-1}\right)$; filled diamond $\mathrm{kr16}\left(20 \mathrm{~g} \mathrm{~L}^{-1}\right)$; $4 \mathrm{kr16}$ (30 $\left.\mathrm{g} \mathrm{L}^{-1}\right)$; P11 $\left(10 \mathrm{~g} \mathrm{~L}^{-1}\right)$; unfilled triangle P11 $\left(20 \mathrm{~g} \mathrm{~L}^{-1}\right)$; unfilled square $\mathrm{P} 11\left(30 \mathrm{~g} \mathrm{~L}^{-1}\right)$

substrate concentration of $30 \mathrm{~g} \mathrm{~L}^{-1}$ for the three bacteria, which was expected, as it has the highest amount of protein. Strains kr16 and P11 had the best results for the acid substrate $\left(0.115\right.$ and $0.178 \mathrm{mg} \mathrm{mL}^{-1}$, respectively). The strain $\mathrm{kr} 6$ reached $0.126 \mathrm{mg} \mathrm{mL}^{-1}$ in alkaline substrate. In most assays, a decrease in the amino acid concentration was found after reaching the highest level, probably due to the consumption of those amino acids as nutrients by the microorganisms. A study by Riffel et al. (2003) with kr6, using chicken feathers as substrate, found that the free amino acid concentration increased up to $48 \mathrm{~h}$, and then stabilized, remaining at about $0.5 \mathrm{mg} \mathrm{mL}^{-1}$. Acting upon the insoluble proteins of the fish protein isolate studied in the present work, kr6 showed a similar behavior to that previously observed (Riffel et al. 2003) although with a lower amount of free amino acids $-0.12 \mathrm{mg} \mathrm{mL}^{-1}$.

Since the highest concentration of free amino acids was reached at $48 \mathrm{~h}$ for most experiments, the factorial design statistical analysis was performed for this incubation time. The statistical analysis was performed by dividing the design in three parts, assessing two bacteria each time. All
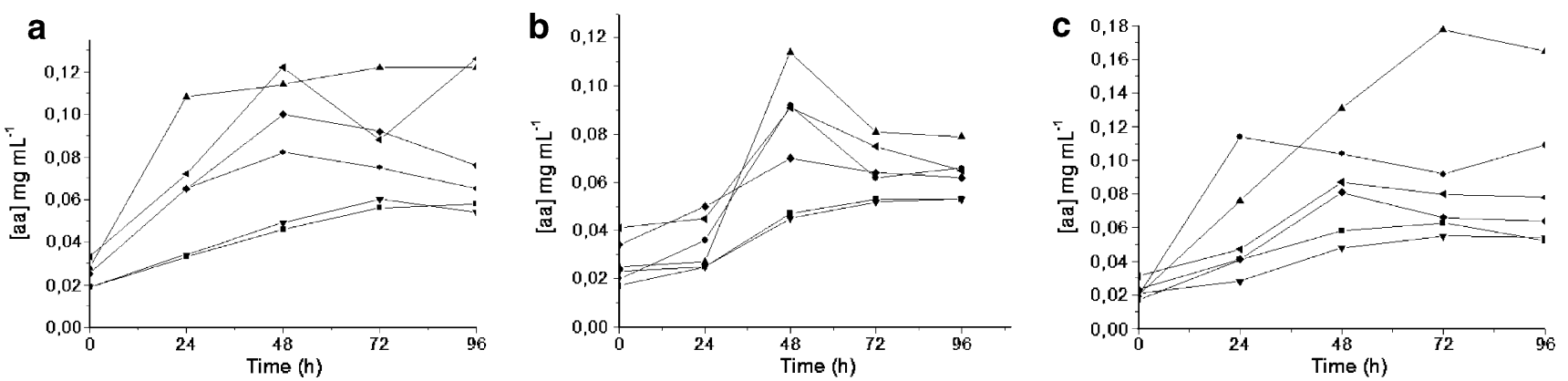

Fig. 2 Free amino acids concentration during the fermentative process for the bacteria, $\mathrm{kr} 6$ (a), $\mathrm{kr} 16$ (b), and $\mathrm{P} 11$ (c). Filled square acid $\left(10 \mathrm{~g} \mathrm{~L}^{-1}\right)$; filled circle acid $\left(20 \mathrm{~g} \mathrm{~L}^{-1}\right)$; filled triangle acid

(30 $\left.\mathrm{g} \mathrm{L}^{-1}\right)$; filled inverted triangle alkaline $\left(10 \mathrm{~g} \mathrm{~L}^{-1}\right)$; filled diamond alkaline $\left(20 \mathrm{~g} \mathrm{~L}^{-1}\right) ; \varangle$ alkaline $\left(30 \mathrm{~g} \mathrm{~L}^{-1}\right)$ 


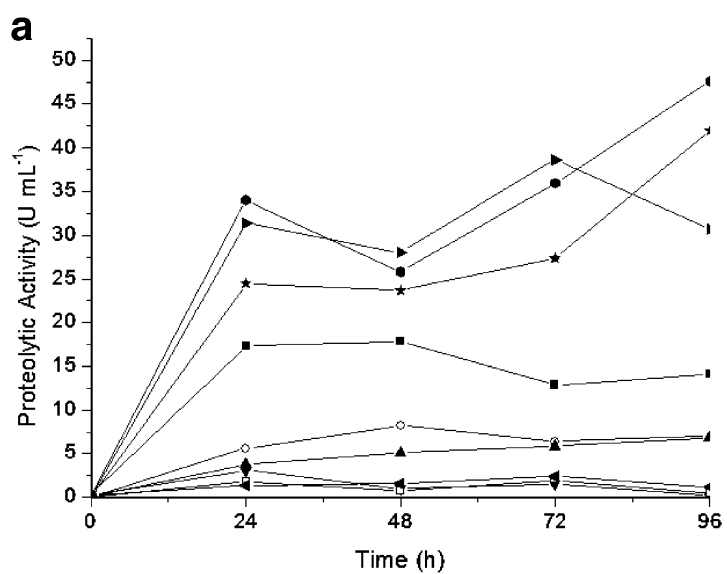

Fig. 3 Proteolytic activity in the acid (a) and alkaline (b) substrates, during the fermentative process with the different bacteria and concentrations. Filled square $\mathrm{kr} 6\left(10 \mathrm{~g} \mathrm{~L}^{-1}\right)$; unfilled circle $\mathrm{kr} 6$

analyses showed a significant difference $(p<0.05)$ for the variable substrate concentration, despite the substrate type and microorganism used. The substrate type also presented a significant difference $(p<0.05)$ between $\mathrm{kr16}$ and P11, thus showing that the acid substrate provided a higher concentration of free amino acids. No significant differences $(p<0.05)$ were found among the bacteria, as expected, since they had very close values (Fig. 2).

\section{Proteolytic Activity}

B. cereus (kr16) presented very low proteolytic activity when compared with the two other bacteria tested. Strains kr6 and P11 reached maximum values of 23 and $47 \mathrm{U} \mathrm{mL}^{-1}$, respectively, whereas kr16 reached a maximum activity of $3 \mathrm{U} \mathrm{mL}^{-1}$. Therefore, it was not assessed in the factorial design along with kr6 and P11. Study accomplished by Casarin et al. (2008) using fish meal and the bacteria Chryseobacterium sp. showed a very low proteolytic activity $\left(1 \mathrm{U} \mathrm{mL}^{-1}\right)$.

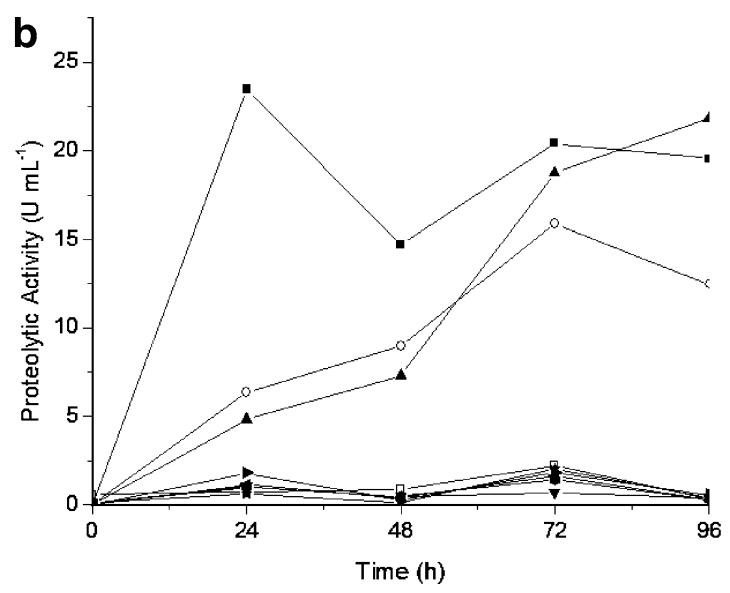

$\left(20 \mathrm{~g} \mathrm{~L}^{-1}\right)$; filled triangle $\mathrm{kr6}\left(30 \mathrm{~g} \mathrm{~L}^{-1}\right)$; filled inverted triangle $\mathrm{kr} 16$ $\left(10 \mathrm{~g} \mathrm{~L}^{-1}\right)$; unfilled square $\mathrm{kr16}\left(20 \mathrm{~g} \mathrm{~L}^{-1}\right) ; \boldsymbol{k r 1 6}\left(30 \mathrm{~g} \mathrm{~L}^{-1}\right) ; \mathrm{P} 11$ $\left(10 \mathrm{~g} \mathrm{~L}^{-1}\right)$; filled circle P11 $\left(20 \mathrm{~g} \mathrm{~L}^{-1}\right)$; filled star P11 $\left(30 \mathrm{~g} \mathrm{~L}^{-1}\right)$

Figure 3 shows the behavior of microorganisms for both acid and alkaline substrates. It can be seen that the highest proteolytic activity was reached when the acid substrate was used. Most experiments presented a reduction in proteolytic activity at $48 \mathrm{~h}$, increasing again after this period. This pattern may suggest that the enzyme is inducible, i.e. substrate levels in the extracellular milieu regulate its secretion (Sangali and Brandelli 2000). These results resemble those observed for cultures of Chryseobacterium sp. (Riffel et al. 2003) and Streptomyces spp. (Sharma and Berwick 1991; Böckle et al. 1995) growing on keratin-rich substrates. The proteolytic activity reached the highest activity at $48 \mathrm{~h}$, coinciding with the end of the exponential phase, then reducing and increasing again at $100 \mathrm{~h}$. Protease production by $B$. cereus growing on chicken feathers showed a comparable trend as the production of soluble protein increased up to $48 \mathrm{~h}$ and then stabilized (Kim et al. 2001). The same behavior was found for B. cereus in our work. Esakkiraj et al. (2008) performed experiments using acid and alkaline hydrolysates of tuna waste for protease production,
Fig. 4 Proteolytic activity on different substrate concentrations and bacteria in the acid (a) and alkaline (b) substrate at $72 \mathrm{~h}$ of fermentation
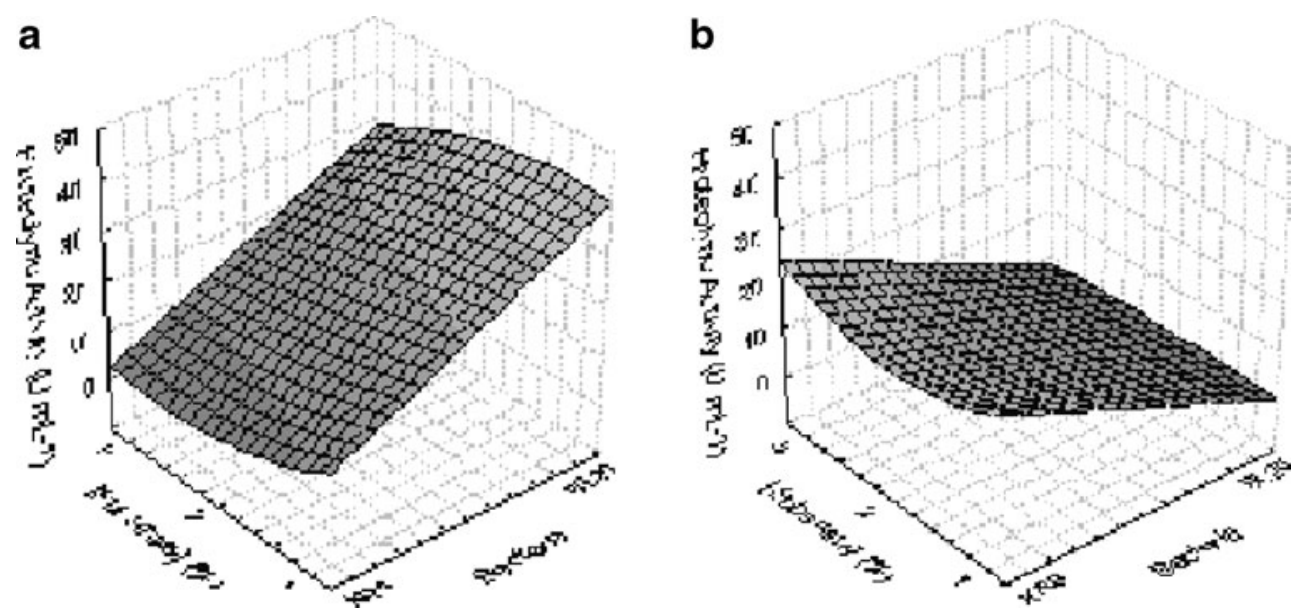
the results showed a protease activity of 60.37 and $65.96 \mathrm{U} \mathrm{mL}^{-1}$, respectively. The maximum were attained at $48 \mathrm{~h}$ of fermentation and it decrease after. They obtained highest values, although we used just the insoluble protein resulting from the acid and alkaline hydrolysates and these authors performed the experiments with the entire protein hydrolysates.

Most proteolytic activity of kr6 and P11 was found to occur at $72 \mathrm{~h}$; therefore, the mixed factorial experimental design $3^{2} \times 2^{1}$ followed that time. The significant variables were the microorganism $(p=0.045)$, substrate type $(p=$ $0.008)$, and the interaction substrate/microorganism ( $p=$ 0.002). The microorganism behavior for the different substrate concentrations and acid and alkaline substrate types is shown in Fig. 4. Results show that in the studied conditions, most proteolytic activity for the acid substrate was reached by using $B$. velesensis $(\mathrm{P} 11)$, in the substrate concentration of $10 \mathrm{~g} \mathrm{~L}^{-1}$. On the other hand, for the alkaline substrate, the best results could be reached using Chryseobacterium sp. (kr6), also in the $10 \mathrm{~g} \mathrm{~L}^{-1}$ substrate concentration.

The substrate concentration not presented statistical significance for the proteolytic activity, this statement agree with Casarin et al. (2008) who studied different substrate concentrations, using the microorganism Chryseobacterium sp. on insoluble proteins. The variable less significant in the fermentative process was the substrate concentration.

\section{Conclusion}

The three bacteria used were capable of solubilize proteins and amino acids from scales, bones, skins, cell membranes, and cartilages, which are contained in the insoluble proteins discarded in the processes of acid and alkaline solubilization conducted with residues of Whitemouth croaker ( $M$. furnieri) processing. The medium percentage of protein hydrolysated with these treatments regardless the bacteria used was between $50-60 \%$.

$B$. velesensis ( $\mathrm{P} 11)$ was the bacterium that presented better results with the analyzed substrates, showing the largest proteolytic activities, and hence achieving larger amount of soluble protein and free amino acids.

Since no study has been found in the literature using residues from chemical hydrolysis of fish protein, three bacteria with keratinolytic activity were used to act upon the insoluble proteins. From the results found, additional investigation could be developed, such as the type of proteases produced during the fermentative process, considering that the type of material hydrolyzed provides evidence for keratinase and collagenase production. The amino acid composition of the resulting hydrolysates could also be studied.
Our laboratory is conducting similar research, examining ten different fungi in submerged fermentation, using the same fish residues as substrate.

The proteins, peptides, and amino acids recovered may be used to increase the yield in traditional processes of fishbased protein concentration. In addition, keratinolytic enzymes from bacteria may have important uses in biotechnological processes involving keratin-containing wastes from fish, poultry, and leather industries through the development of nonpolluting processes. Insoluble keratins can be converted after enzymatic hydrolysis to feedstuffs, fertilizers, glues, and films, used for the production of the rare amino acids serine, cysteine, and proline.

Acknowledgments The authors thank the National Council for Scientific and Technological Development of Brazil (CNPq) for the financial support.

\section{References}

Anwar, A., \& Saleemuddin, M. (1998). Alkaline proteases: a review. Bioresource Technology, 64, 175-183. doi:10.1016/S0960-8524 (97)00182-X.

Aspmo, S. I., Horn, S. J., \& Eijsink, V. G. H. (2005). Enzymatic hydrolysis of Atlantic cod (Gadus morhua L.) viscera. Process Biochemistry, 40, 1957-1966. doi:10.1016/j.procbio.2004.07.011.

Aurrekoetxea, G., \& Perera, M. N. (2001). Aprovechamiento de recursos pesqueros infrautilizados para la obtención de alimentos mejorados de peces de acuicultura. AquaTIC, 13, maio 2001 [available at 13/01/2004 em URL: http://www.revista aquatic. com/aquatic/art.asp?t=\&c=105].

Böckle, B., Galunski, B., \& Müller, R. (1995). Characterization of a keratinolytic serine protease from Streptomyces pactum DSM40530. Applied and Environmental Microbiology, 61, 3705-3710.

Brandelli, A. (2008). Bacterial keratinases: useful enzymes for bioprocessing agroindustrial wastes and beyond. Food Bioprocess Technol, 1, 105-116. doi:10.1007/s11947-007-0025-y.

Casarin, F., Oliveira, F. C., \& Brandelli, A. (2008). Use of poultry byproduct for production of keratinolytic enzymes. Food and Bioprocess Technology, 1, 301-305. doi:10.1007/s11947-0080091-9.

Costa, P. G., Fontana, A., \& Prentice, C. H. (2005). Obtención y caracterización de un aislado proteico proveniente de la matriz de exoesqueletos de camarón rosado (Farfantepenaeus paulensis). Alimentaria, 42, 82-89.

Esakkiraj, P., Immanuel, G., Sowmya, S. M., Iyapparaj, P., \& Palavesan, A. (2008). Evaluation of protease-producing ability of fish gut isolate Bacillus cereus for aqua feed. Food and Bioprocess Technology, In press. doi:10.1007/s11947-007-0046-6.

Gildberg, A., Arnesen, J. A., \& Carlehög, M. (2002). Utilization of cod backbone by biochemical fractionation. Process Biochemistry, 38, 475-480. doi:10.1016/S0032-9592(02)00103-6.

Giongo, J. L., Lucas, F. S., Casarin, F., Heeb, P., \& Brandelli, A. (2007). Keratinolytic proteases of Bacillus species isolated from the Amazon basin showing remarkable de-hairing activity. World Journal of Microbiology \& Biotechnology, 23, 375-382. doi:10.1007/s11274-006-9234-1.

Gupta, R., \& Ramnani, P. (2006). Microbial keratinases and their prospective applications: an overview. Applied Microbiology and Biotechnology, 70, 21-33. doi:10.1007/s00253-005-0239-8. 
Hulse, J. H. (2004). Biotechnologies: past history, present state and future prospect. Trends in Food Science \& Technology, 15, 3-18. doi:10.1016/S0924-2244(03)00157-2.

Jooste, P. J., \& Britz, T. J. (1986). The significance of Flavobacteria as proteolytic psychrotrophs in milk. Milk Science International, $41,618-621$.

Kim, J. M., Lim, W. J., \& Suh, H. J. (2001). Feather-degrading Bacillus species from poultry waste. Process Biochemistry, 37, 287-291. doi:10.1016/S0032-9592(01)00206-0.

Kristinsson, H. G., \& Ingadottir, B. (2006). Recovery and properties of muscle proteins extracted from tilapia (Oreochromis niloticus) light muscle by ph shift processing. Journal of Food Science, 71, E132-41. doi:10.1111/j.1750-3841.2006.00046.x.

Kristinsson, H. G., \& Liang, Y. (2006). Effect of pH-shift processing and surimi processing on Atlantic croaker (Micropogonias undulates) muscle proteins. Journal of Food Science, 71, C304-C312. doi:10.1111/j.1750-3841.2006.00046.x.

Lempek, T. S., Martins, V. G., \& Prentice, C. H. (2007). Rheology of surimi-based products from fatty fish underutilized by the industry: Argentine croaker (Umbrina canosai). Journal of Aquatic Food Product Technology, 16, 27-44. doi:10.1300/ J030v16n04_04.

Lin, X., Inglis, G. D., Yanke, L. J., \& Cheng, K. J. (1999). Selection and characterization of feather degrading bacteria from canola meal compost. Journal of Industrial Microbiology \& Biotechnology, 23, 149-153. doi:10.1038/sj.jim.2900706.

Lowry, O. H., Rosebrough, N. J., Farr, A. L., \& Randall, R. J. (1951). Protein measurement with the Folin phenol reagent. Journal of Biological Chemistry, 193, 267-275.

Luiten, E. E. M., Akkerman, I., Koulman, A., Kamermans, P., Reith, H., Barbosa, M. J., et al. (2003). Realizing the promises of marine biotechnology. Biomolecular Engineering, 20, 429-439. doi:10.1016/S1389-0344(03)00074-1.

Miller, A., \& Parker, S. B. (1984). Collagen: the organic matrix of bone. Philosophical Transactions of the Royal Society of London. Series B, Biological Sciences, 304, 455-477. doi:10.1098/rstb. 1984.0040 .

Moore, S. (1968). Amino acid analysis: aqueous DMSO as solvent for the ninhydrin reaction. Journal of Biological Chemistry, 243, $6281-6283$.

Onifade, A. A., Al-Sane, N. A., Al-Musallam, A. A., \& Al-Zarban, S. (1998). Potentials for biotechnological applications of keratindegrading microorganisms and their enzymes for nutritional improvement of feathers and other keratins as livestock feed resources. Bioresource Technology, 66, 1-11. doi:10.1016/S09608524(98)00033-9.

Papadopoulos, M. C., El-Boushy, A. R., Roodbeen, A. E., \& Ketelaars, E. H. (1986). Effects of processing time and moisture content on aminoacid composition and nitrogen characteristics of feather meal. Animal Feed Science and Technology, 14, 279-290. doi:10.1016/0377-8401(86)90100-8.

Parry, D. A. D., \& North, A. C. T. (1998). Hard $\alpha$-keratin intermediate filament chains: substructure of the $\mathrm{N}$ - and $\mathrm{C}$-terminal domains and the predicted structure and function of the $\mathrm{C}$-terminal domain soft type I and type II chains. Journal of Structural Biology, 122, 67-75. doi:10.1006/jsbi.1998.3967.

Pérez-Mateos, M., Amato, P. M., \& Lanier, T. C. (2004). Gelling properties of Atlantic croaker surimi processed by acid or alkaline solubilization. Journal of Food Science, 69, FCT328-FCT333.

Riffel, A., Lucas, F., Heeb, P., \& Brandelli, A. (2003). Characterization of a new keratinolytic bacterium that completely degrades native feather keratin. Archives of Microbiology, 179, 258-265.

Riffel, A., Brandelli, A., Bellato, C. M., Souza, G. H. M. F., Eberlin, M. N., \& Tavares, F. C. A. (2007). Purification and characterization of a keratinolytic metalloprotease from Chryseobacterium sp. kr6. Journal of Biotechnology, 128, 693-703. doi:10.1016/j. jbiotec.2006.11.007.

Sangali, S., \& Brandelli, A. (2000). Isolation and characterization of a novel feather-degrading bacterial strain. Applied Biochemistry and Biotechnology, 87, 17-24. doi:10.1385/ABAB:87:1:17.

Santos, S. D. (2006). Obtenção e avaliação de hidrolisado enzimático obtido a partir de pescado de baixo valor comercial. Dissertação de Mestrado em Engenharia e Ciência de Alimentos, Universidade Federal do Rio Grande, 2006, Brazil.

Sharma, G., \& Berwick, P. G. (1991). Production of keratinolytic enzymes in a rotating frame bioreactor. Biotechnology Techniques, 5, 359-362.

Shih, J. C. H. (1993). Recent development in poultry waste digestion and feather utilization - a review. Poultry Science, 72, 1617-1620.

Slizyte, R., Dauksas, E., Falch, E., Storro, I., \& Rustad, T. (2005). Characteristics of protein fractions generated from hydrolysed cod (Gadus morhus) by-products. Process Biochemistry, 40, 2021-2033. doi:10.1016/j.procbio.2004.07.016.

Suh, H. J., \& Lee, H. K. (2001). Characterization of a keratinolytic serine protease from Bacillus subtilis KS-1. Journal Protein Chemistry, 20, 165-169. doi:10.1023/A:1011075707553.

Thys, R. C. S., Lucas, F. S., Riffel, A., Heeb, P., \& Brandelli, A. (2004). Characterization of a protease of a feather degrading Microbacterium species. Letters in Applied Microbiology, 39, 181-186. doi:10.1111/j.1472-765X.2004.01558.x.

Vieille, C., \& Zeikus, G. J. (2001). Hyperthermophilic enzymes: sources, uses, and molecular mechanisms for thermostability. Microbiology and Molecular Biology Reviews, 65, 1-43. doi:10.1128/MMBR.65.1.1-43.2001.

Wang, X., \& Parsons, C. M. (1997). Effect of processing systems on protein quality of feather meal and hog hair meals. Poultry Science, 76, 491-496.

Watanabe, K. (2004). Collagenolytic proteases from bacteria. Applied Microbiology and Biotechnology, 63, 520-526. doi:10.1007/ s00253-003-1442-0.

Werlang, P. O., \& Brandelli, A. (2005). Characterization of a novel feather-degrading Bacillus sp. strain. Applied Biochemistry and Biotechnology, 120, 71-80. doi:10.1385/ABAB:120:1:71.

Yamaguchi, S., \& Yokoe, M. A. (2000). Novel protein-deamidating enzyme from Chryseobacterium proteolyticum sp. Nov. a newly isolated bacterium from soil. Applied and Environmental Microbiology, 66, 3337-3343. doi:10.1128/AEM.66.8.33373343.2000 